\title{
Energy Consumption Pattern of a Decentralized Community in Oyo State, Nigeria
}

\author{
Odesola Isaac F. ${ }^{1}$, Awoyemi Omotola ${ }^{1}$, Folorunso Amos ${ }^{1 *}$
}

${ }^{1}$ Department of Mechanical Engineering,

University of Ibadan, Ibadan, 200284, NIGERIA

* Corresponding Author

DOI: https://doi.org/10.30880/jamea.2020.01.02.004

Received 22 July 2020; Accepted 15 September 2020; Available online 31 October 2020

\begin{abstract}
Energy is required in the manufacturing process of various products and in the movement of goods and services within and outside a country. Energy consumption patterns, which consist of energy sources, quantities and the demographics of the consumers, help in drawing a clearer picture of the economic situation of the location. This work involves a survey of the energy consumption pattern carried out in a decentralized community. As established from the research, there is a direct correlation between economic development and energy consumption. It is therefore imperative to study the energy usage in rural areas to help decision makers tackle their energy problems. A survey questionnaire was designed for this study and energy conversion method was employed for the conversion of the raw data collected into energy units to determine the quantities of energy consumed in various sectors at the Alagbaa community in Akanran, Ona Ara Local Government Area, Oyo State, Nigeria. The survey covered a heterogeneous population of different income groups and social groups. Studies were carried out on the total and average quantities of energy consumed in the domestic (cooking and home electrification), transportation and agricultural sectors. Home electrification accounted for $37 \%$ of the total energy used while transportation, cooking and agriculture accounted for 35\%, 13\% and 15\% respectively. From the study, it was found that economic inequality is also displayed in the choice of energy sources with higher deviation found in the total amount energy consumption. It was also realized that the least conventional source of energy, firewood, showed higher deviation. It also revealed that $50 \%$ of the energy used was channelled to non-economic activities.
\end{abstract}

Keywords: Energy, community, domestic, agriculture, transportation

\section{Introduction}

Nigeria is a country with an estimated population of 170 million people and a landmass of $923,768 \mathrm{~km}^{2}$ has 774 local governments. Within each local government, there are many towns and villages, many of which are of a decentralized nature. Oyo State is a state in the southwest geopolitical zone of Nigeria. According to the 2006 census figures, the population of Oyo State stood at a figure of 5,591,589 people with an annual population growth rate of 3.35\%. The population density was 197.6 persons/ $\mathrm{km}^{2}$, with $70 \%$ of Oyo State living in rural communities [1]. In 2017, the total energy supply for biofuels and waste was $74.4 \%$, oil $16.3 \%$, natural gas $9.0 \%$, and hydropower $0.3 \%$ [2]. Irrespective of the abundant fossil fuel resources available in the country, a significant proportion of the energy consumption is sourced by biofuels and wastes. The most typical biofuel used is firewood [2].

In the present economic scenario, the critical concerns in energy policymaking in Nigeria are: how to achieve higher energy efficiency in key sectors of the economy and how to reduce the vulnerability of the economy to external shocks like falls in the price of crude oil in the global market as there is a close relationship between energy consumption and economic growth [3] - [6]. The energy planning should be based on the existing levels of energy consumption [7]. However, the information available in the published form needed for this is either at the state or national levels. Energy surveys for specific regions display the region's economic development status and reveal areas and economic sectors 
where a government needs to channel more resources. Devadas [8] highlighted that regional developmental activities have to be based on detailed information from each sector. In his work, he drew attention to significant discrepancies between data collected from primary and secondary sources, justifying the need for a micro-level analysis. Hence, a detailed energy survey needs to be conducted by visiting and consulting the community's local people. This justifies the need for a study to be carried out to understand the domestic energy use patterns in various socioeconomic sectors.

The economic growth of a nation majorly depends on the rate of energy consumption, and this was initially studied by Kraft and Kraft [9], where it was eventually established that there is evidence of unidirectional causality from Gross National Product (GNP) to energy usage in the United States throughout 1947-1974. Energy policies must meet the energy demand by its appropriate energy supply to achieve sustainable economic growth and development. The successful implementation of an energy plan depends on an accurate estimation of energy demand and resource availability. Therefore, the study was initiated to establish energy consumption information from a household survey of the heterogeneous population of diverse income, education and social groups within the Alagbaa community in Oyo State. The total energy consumed in the domestic, transportation, and agricultural sectors was due to conventional and non-conventional energy sources. The results from this study are useful for national and regional energy policies leading to the technological and economic development of the rural sector.

In a research paper by Sachin et al. [10], it was realized that most energy planning exercises are carried out with aggregate data at the national level. The authors further stated that the successful implementation of an energy plan depends on an accurate estimation of energy demand and resource availability. The energy demand can be estimated based on the per capita energy needed by a region and can be used as the most appropriate basis for future estimation of energy requirements. The energy resource availability can be estimated based on available conversion technologies and methods.

Gbadebo and Okonkwo [4] investigate the relationship between energy consumption and the Nigerian economy from 1970 to 2005. The study applied the co-integration technique and the results derived infer that there exists a positive relationship between energy consumption and economic growth at the period. The study implies that increased energy consumption is a strong determinant of economic growth, as shown in other studies in different countries at different time intervals [3]. A similar conclusion was arrived at by studying Benin, Congo, Kenya and Zimbabwe from 1971 to 2011. A comparable conclusion can be concluded from studies carried out in Turkey and China [5, 6] where researchers investigated the existence of a long-term relationship between energy consumption and real Gross Domestic Product (GDP). The direction of causality from real GDP to energy consumption shows that the production of goods and services depends on energy consumption. This also leads to the causality of carbon dioxide $\left(\mathrm{CO}_{2}\right)$ emissions. Omotor [11] also investigates the relationship between economic growth and energy consumption, where the Hsiao's Granger causality model was used to reveal any correlation. However, the researcher suggests that Nigeria's energy conservation policy would inhibit the country's economic growth.

The studies on energy consumption patterns and the available energy sources in selected rural areas of Benue State, Nigeria were assessed by Ibrahim and Ukwenya [12]. The rural population in the area relies more on fuelwood as their source of energy. It was estimated that the average daily fuelwood and kerosene consumption per household ranged between 9-20 kg and 0.02-0.1 liter, respectively. Through statistical methods, they discovered that the correlation coefficients between household size and quantities of fuelwood and kerosene consumed by respondents are 0.914 and 0.812 , respectively with correlation are deemed statistically significant at the $5 \%$ probability level. It was suggested that solar energy systems need to be deployed to rural areas for efficient resource management and utilization. Furthermore, Li et al. [13] found out that energy consumption patterns differ from communities in different areas with different geographical characteristics. They conducted a study involving 371 rural households in different villages in the Loess hilly region of Gansu Province, China. The study revealed that access to different energy sources available in their locations and economic conditions influenced energy use.

A study was also carried out to examine the end-users attitude towards energy consumption. Olufemi et al. [14] have obtained and compare the data obtained from the prepaid and post-paid metering systems usage in low-income and highincome housing types located in the southwest of Nigeria. The results indicated that about $38 \%$ and $23 \%$ reduction in global warming and acidification potential are achieved by switching to prepaid meters for both income earners. Postpaid low-income earners utilized the highest energy $(59.8 \mathrm{~kW} / \mathrm{hr})$ while the prepaid high-income earners had the minimum $(31.1 \mathrm{KW} / \mathrm{hr})$. The study was able to show that most consumers are accountable in terms of energy utilization with the introduction of the prepaid metering system. It was further observed that high-income earners demonstrated a lower propensity to reduce energy wastage due to the high energy demand associated with their lifestyle.

A study was conducted on the energy consumption pattern in India's rural and urban areas [15]. A case study was Rourkela, Sundergarh District of Odisha from 5-27th December 2013. The exercise was carried out from the humanities and social development perspective. Factors that determined the consumption of electrical energy of rural and urban areas, namely; imbalances in the price of electricity, household income, household size, possession of electrical and electronic gadgets and the climate predominant in the region were identified. It has been established that many researchers have made various contributions towards the determination of the energy consumption patterns of regions in different parts of the world including Nigeria. To this effect, different approaches and methods have been adopted. However, there is still a knowledge gap as very little has been done in the rural communities in Oyo state. The energy data provided for 
the country is available at the national, state and local government levels. This setback is a strong motivation for this study.

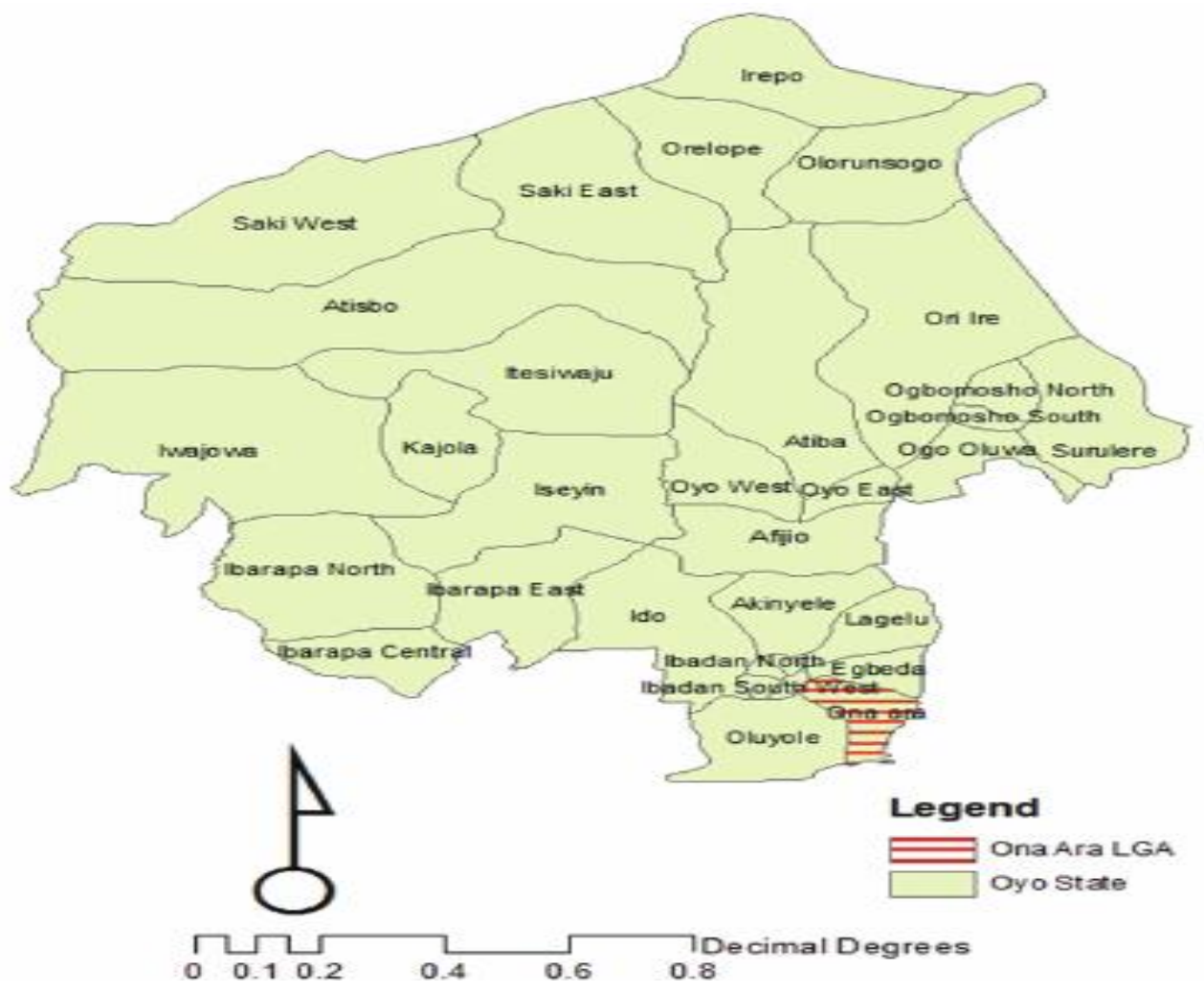

Fig. 1 - Map of Oyo State showing the study area

\section{Methodology}

The decentralized community selected for the present work is Alagbaa village, in Akanran town, Ona Ara Local Government Area of Oyo State, Nigeria as shown in Figure 1. It is located $5.8 \mathrm{~km}$ from Ibadan in the southeast direction. The community of approximately 3000 inhabitants has a heterogeneous population belonging to various income and social groups (Table 1). An energy survey was carried out in September 2015, where this period corresponds to the tropical wet season, which occurs from March to October [16].

Table 1 - Features of Alagbaa community, Akanran, from the survey conducted

\begin{tabular}{|c|c|}
\hline Description & Comment \\
\hline Human population & 3000 \\
\hline Animals present & Dogs, fowls, goats, rams (150, 2500, 300 and 150 respectively) \\
\hline Energy resources present & $\begin{array}{l}\text { Conventional energy sources like petrol, diesel, kerosene and cooking gas } \\
\text { (LPG), and non-conventional energy sources like charcoal, firewood, } \\
\text { electricity and solar energy. }\end{array}$ \\
\hline Employment & Farming, welding, teaching, driving, etc. \\
\hline Major crop types & Cassava, corn, plantain, banana, yam, leafy vegetables \\
\hline Drinking water resources & $\begin{array}{l}\text { Drinking water obtained from well, non-drinking water obtained from a } \\
\text { stream }\end{array}$ \\
\hline $\begin{array}{l}\text { Schools/churches/mosques/ } \\
\text { police stations/ etc. }\end{array}$ & $\begin{array}{l}\text { Alagbaa Community Grammar School, St. James Primary School, No } \\
\text { police station }\end{array}$ \\
\hline
\end{tabular}

Using a survey questionnaire method of data collection, random sampling was used for selecting the respondents for the data. This was done using a door-to-door approach (140 households) to obtain the total amount of energy used from the various energy sources available in the village. The energy data obtained were categorized into the domestic, transportation and agricultural sectors. The domestic sector has been further subdivided into cooking, and household 
electrification, representing the energy used to power the household's electrical appliances. Energy conversion methods were used to convert the raw data from the survey into energy units (Tables 2 and 3). The sum, average, maximum and minimum, and standard deviation were obtained from energy used under the various sectors.

The average quantities of energy consumed in the domestic, transportation and agricultural sectors along with the standard deviation were determined using the following equations:

$$
\mu=\sum x / N
$$

where, $\sum x$ denotes the summation of all data points and $\mathrm{N}$ is the number of data points. The population standard deviation is given as follows:

$$
\sigma=\sqrt{\frac{1}{N} \sum_{i=1}^{N}\left(x_{i}-\mu\right)^{2}}
$$

where $\sigma$ is the standard deviation, $x_{i}$ is the individual $x$ data points and $\mu$ is the population average. The sample standard deviation, $s$ is calculated using the following formula:

$$
s=\sqrt{\frac{1}{N-1} \sum_{i=1}^{N}\left(x_{i}-\bar{x}\right)^{2}}
$$

Table 2 - Conversion factors for energy units

\begin{tabular}{lccccc}
\hline UNITS & $\mathbf{( M J )}$ & KWH & KgSKE & KgOE & MCal \\
\hline $1 \mathrm{MJ}$ & 1.000 & 0.278 & 0.034 & 0.024 & 0.239 \\
$1 \mathrm{KWh}$ & 3.600 & 1.000 & 0.123 & 0.086 & 0.860 \\
$1 \mathrm{KgSKE}$ & 29.310 & 8.140 & 1.000 & 0.700 & 7.000 \\
$1 \mathrm{KgOE}$ & 41.910 & 11.630 & 1.430 & 1.000 & 10.010 \\
$1 \mathrm{MCal}$ & 4.187 & 1.163 & 0.143 & 0.100 & 1.000 \\
\hline
\end{tabular}

Source: Bioenergy Data, Austria Biomass Association Basic (2000)

Note: $\mathrm{MJ}=$ Megajoule, $\mathrm{Kwh}=$ kilowatt hour, $\mathrm{KgSKE}$ = kilogram coal equivalent, $\mathrm{Kg} \mathrm{OE}=$

kilogram oil equivalent, $\mathrm{Mcal}=$ Magacalone

Table 3 - Energy Conversion Method. Source: ${ }^{1}[17],{ }^{2}[18],{ }^{3}[19],{ }^{4}[20],{ }^{5}[21]$.

\begin{tabular}{ll}
\hline Energy Source & \multicolumn{1}{c}{ Methodology } \\
\hline Petrol $^{1}$ & $34.20 \mathrm{MJ} / \mathrm{L}$ \\
Diesel $^{1}$ & $38.60 \mathrm{MJ} / \mathrm{L}$ \\
Kerosene $^{1}$ & $36.60 \mathrm{MJ} / \mathrm{L}$ \\
$\mathrm{LPG}^{1}$ & $49.50 \mathrm{MJ} / \mathrm{kg} / \mathrm{L}$ \\
Firewood $^{1}$ & $16.20 \mathrm{MJ} / \mathrm{kg}$ \\
Charcoal $^{2}$ & $30.00 \mathrm{MJ} / \mathrm{kg}$ \\
Electricity $^{3}$ & Monthly fixed charges $=\mathrm{N} 625.00 ;$ Charge per $\mathrm{kW} \cdot \mathrm{h}=\mathrm{N} 18.00$ \\
Solar $^{4}$ & Daily solar radiation in the community and its environs in September $=12.80 \mathrm{MJ} / \mathrm{m}^{2}$ \\
Human labour $^{5}$ & (a) Adult men Man-hour $1.96 \mathrm{MJ} / \mathrm{hr}$ \\
& (b) Women Woman-hour $1.57 \mathrm{MJ} / \mathrm{hr}(1$ Adult woman $=0.8$ adult man $)$ \\
& (c) Children Child-hour $0.98 \mathrm{MJ} / \mathrm{hr}(1$ child $=0.50$ adult man $)$ \\
\hline
\end{tabular}

\section{Results}

A total of 140 households were surveyed in this study. The households are of heterogeneous background: households of different populations, employed in different economic sectors, comprising different age groups and educational attainment levels. The energy sources used to perform tasks in the community include kerosene, gasoline, diesel, 
Liquefied Petroleum Gas (LPG), firewood, charcoal, solar, electricity, and energy from human labour. The total energy consumed and the consumption patterns in the domestic sector (cooking and house electrification), transportation, and agricultural sectors were calculated from the analysis carried out. The ratios and amounts of different energy sources and how much they were used in different community sectors were estimated.

The total energy used daily by the households surveyed is $24362 \mathrm{MJ}$. The average daily energy used per household is $174 \mathrm{MJ}$, while the minimum and maximum energy used stood at $18.95 \mathrm{MJ}$ and $539.28 \mathrm{MJ}$ as shown in Table 4 below.

Table 4 - Daily energy consumption in Alagbaa community

\begin{tabular}{lccccc}
\hline & Minimum (MJ) & Maximum (MJ) & Sum (MJ) & Mean (MJ) & Std. Deviation \\
\hline Energy Consumption & 18.95 & 539.28 & 24362.03 & 174.01 & 91.25 \\
\hline
\end{tabular}

\subsection{Energy consumption pattern}

The description of the energy used in the following sectors: Domestic (cooking, house electrification), transportation, and agriculture are shown in Table 5 below and further described in the sub-sections below.

Table 5 - Daily energy consumption in different sectors in the Alagbaa community

\begin{tabular}{lccccc}
\hline Energy Source & $\begin{array}{c}\text { Minimum } \\
(\mathbf{M J})\end{array}$ & $\begin{array}{c}\text { Maximum } \\
(\mathbf{M J})\end{array}$ & $\begin{array}{c}\text { Sum } \\
(\mathbf{M J})\end{array}$ & $\begin{array}{c}\text { Mean } \\
(\mathbf{M J})\end{array}$ & Std. Deviation \\
\hline Cooking & 2.31 & 68.57 & 3147.87 & 22.48 & 15.50 \\
Electrification & 0.00 & 182.40 & 9173.00 & 65.52 & 37.60 \\
Transportation & 0.00 & 390.86 & 8471.39 & 60.51 & 61.98 \\
Agriculture & 0.00 & 266.29 & 3569.78 & 25.50 & 47.92 \\
\hline
\end{tabular}

The distribution of the energy used in different sectors in the community is shown in Figure 2 below.

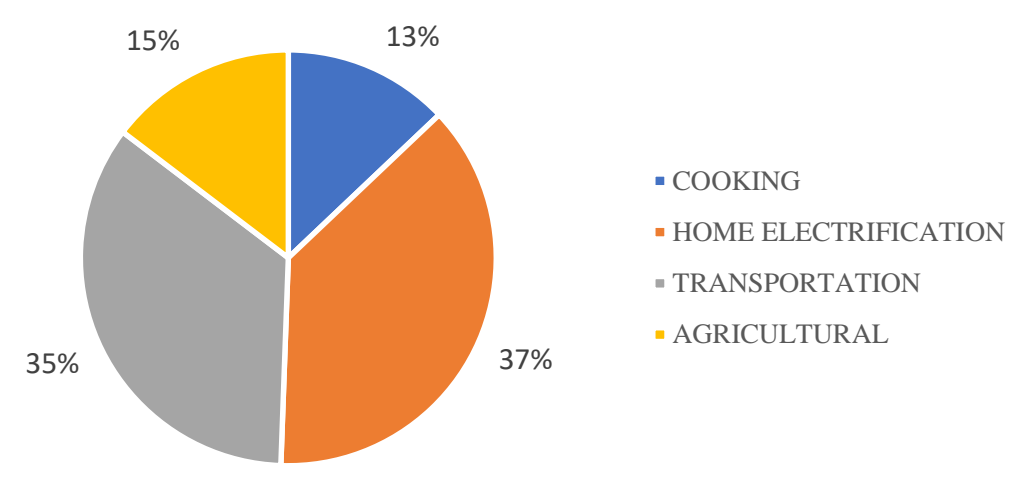

Fig. 2 - Distribution of energy consumed in different sectors of the Alagbaa community.

\subsubsection{Domestic sector- Cooking}

The primary energy sources used in cooking are kerosene, charcoal, firewood, and cooking gas- LPG. The survey shows that no household in the Alagbaa community uses electricity or sawdust as a source of energy for cooking. The most used energy source is kerosene $(41 \%, 1299.04 \mathrm{MJ})$, while firewood was the next source (38\%, 1192.98 MJ) as seen in Table 6 and Figure 3. The average energy used for cooking per household is 22.48MJ (Table 5). Kerosene and cooking gas are consumed with kerosene stoves and domestic gas burners of various sizes manufactured in Asian countries, while firewood and charcoal are burned in locally manufactured stoves made of metal, stones or clay.

Kerosene and firewood represented the largest energy source used for cooking (1299.04 MJ, 41\% and $1192.98 \mathrm{MJ}$, $38 \%$ respectively). This is due to the availability of firewood naturally and also the availability of low-priced kerosene. Public transportation consumes 7\% (566.30 MJ) of the total energy consumed for transportation (8471.39 MJ). 
Table 6 - Daily energy used for cooking from different sectors

\begin{tabular}{lccccc}
\hline Energy Source & $\begin{array}{c}\text { Minimum } \\
(\mathbf{M J})\end{array}$ & $\begin{array}{c}\text { Maximum } \\
(\mathbf{M J})\end{array}$ & $\begin{array}{c}\text { Sum } \\
(\mathbf{M J})\end{array}$ & $\begin{array}{c}\text { Mean } \\
(\mathbf{M J})\end{array}$ & $\begin{array}{c}\text { Std. } \\
\text { Deviation }\end{array}$ \\
\hline Charcoal & 0.00 & 68.57 & 115.71 & 0.83 & 6.12 \\
Firewood & 0.00 & 57.86 & 1192.98 & 8.52 & 16.42 \\
Kerosene & 0.00 & 31.37 & 1299.04 & 9.28 & 9.01 \\
LPG & 0.00 & 49.10 & 540.10 & 3.86 & 10.53 \\
\hline
\end{tabular}

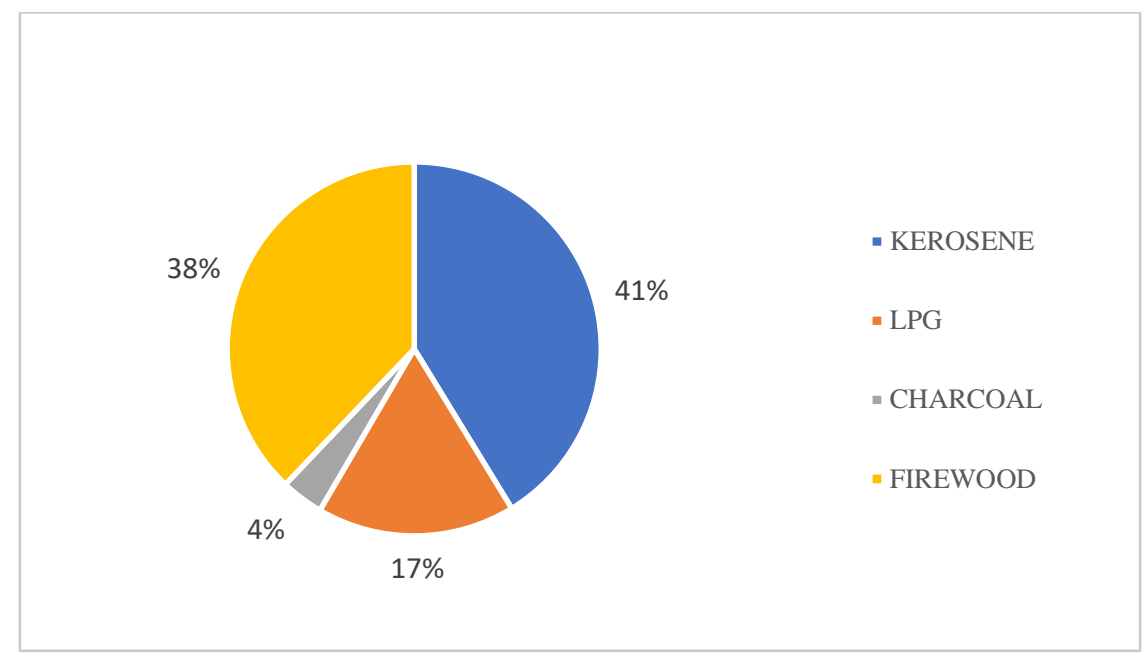

Fig. 3 - Distribution of energy used for cooking from various sources.

\subsubsection{Domestic sector - Home electrification}

The survey found that only $54.3 \%$ of the community's households receive electric power from the Ibadan Electricity Distribution Company (IBEDC). However, 97.1\% of the households own an electric generating set, all of them gasolinepowered as shown in Table 7. The majority of the energy consumed under this sector comes from the generating sets. Electrical companies consume 790.33MJ of energy (Table 8), representing approximately 9\% of this sector's total energy consumption (Figure 3). The survey analysis discovered that up to $94.3 \%$ of the community households own a TV set and $60.7 \%$ own fans as shown in Table 9.

It is found that $97 \%$ of the households surveyed owned electric generators, converting the fuel's chemical energy into electric energy at low efficiencies. Many community households do not receive power from the Ibadan Electricity Distribution Company (45.7\%).

Table 7 - House electrification frequency distribution

\begin{tabular}{lcc}
\hline Description & Number & Percentage (\%) \\
\hline Households that receive electricity from IBEDC & 76 & 54.30 \\
\hline Households that own a generator & 136 & 97.10 \\
\hline Generators powered with gasoline & 136 & 100.00 \\
\hline $\begin{array}{l}\text { Generators powered } \\
\text { with diesel }\end{array}$ & 0 & 0.00
\end{tabular}

Table 8 - Daily energy used for house electrification

\begin{tabular}{lccccc}
\hline Energy & $\begin{array}{c}\text { Minimum } \\
(\mathbf{M J})\end{array}$ & $\begin{array}{c}\text { Maximum } \\
(\mathbf{M J})\end{array}$ & $\begin{array}{c}\text { Sum } \\
(\mathbf{M J})\end{array}$ & $\begin{array}{c}\text { Mean } \\
(\mathbf{M J})\end{array}$ & $\begin{array}{c}\text { Std. } \\
\text { Deviation }\end{array}$ \\
\hline Self-generated & 0.00 & 146.57 & 8382.66 & 59.88 & 35.46 \\
IBEDC & 0.00 & 49.17 & 790.33 & 5.65 & 8.48 \\
\hline
\end{tabular}


Table 9 - Frequency distribution of house appliances

\begin{tabular}{lcccccc}
\hline & TV & Fridge & Antenna & Fan & $\begin{array}{c}\text { Air } \\
\text { conditioner }\end{array}$ & $\begin{array}{c}\text { Water } \\
\text { pumping } \\
\text { machine }\end{array}$ \\
\hline Number & 132 & 68 & 55 & 85 & 34 & 37 \\
Percentage $(\%)$ & 94.30 & 48.60 & 39.30 & 60.70 & 24.30 & 26.40 \\
\hline
\end{tabular}

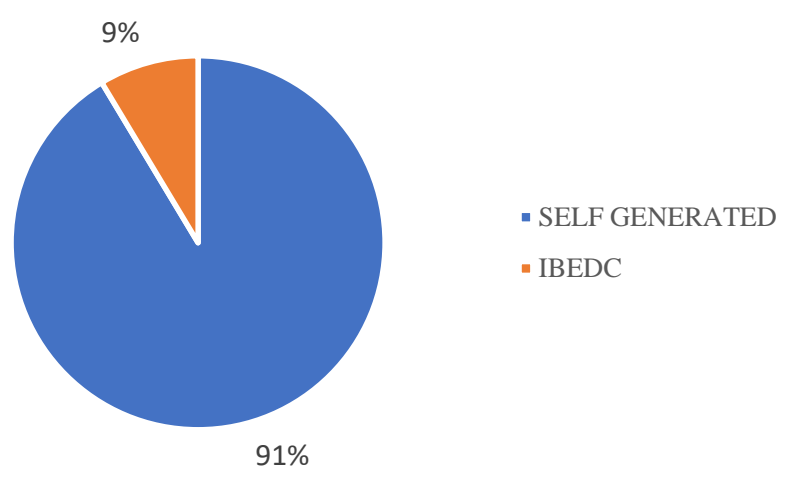

Fig. 4 - Distribution of energy used for home electrification

\subsubsection{Transportation}

The vehicles for transportation for both goods and people in the community include cars, motorcycles, trucks, trailers, tricycles and buses. The total amount of energy consumed daily for transportation is $8471 \mathrm{MJ}$ as shown in Table 4 . However, 7\% (566.3 MJ) of energy distribution comes from the public transportation system (Figure 5 and Table 10), mainly buses, motorcycles, and tricycles. In contrast, private transportation accounted for the remaining $93 \%$ (7905.1 MJ). A total of $78.1 \%$ of the households surveyed owned at least a vehicle (Table 11).

Table 10 - Daily energy used for transportation

\begin{tabular}{lccccc}
\hline & $\begin{array}{c}\text { Minimum } \\
(\mathbf{M J})\end{array}$ & $\begin{array}{c}\text { Maximum } \\
\text { (MJ) }\end{array}$ & Sum (MJ) & Mean (MJ) & $\begin{array}{c}\text { Std. } \\
\text { Deviation }\end{array}$ \\
\hline Public Transportation & 0.00 & 24.43 & 566.30 & 4.05 & 4.18 \\
Private Transportation & 0.00 & 390.86 & 7905.09 & 56.46 & 61.97 \\
\hline
\end{tabular}

Table 11 - Frequency distribution of vehicles used by the surveyed households

\begin{tabular}{lccccccc}
\hline & Car & Motorcycle & Truck & Trailer & Tricycle & Bus & None \\
\hline Number & 64 & 18 & 2 & 6 & 6 & 10 & 32 \\
Percentage $(\%)$ & 45.70 & 12.90 & 1.40 & 4.30 & 4.30 & 7.10 & 22.90 \\
\hline
\end{tabular}

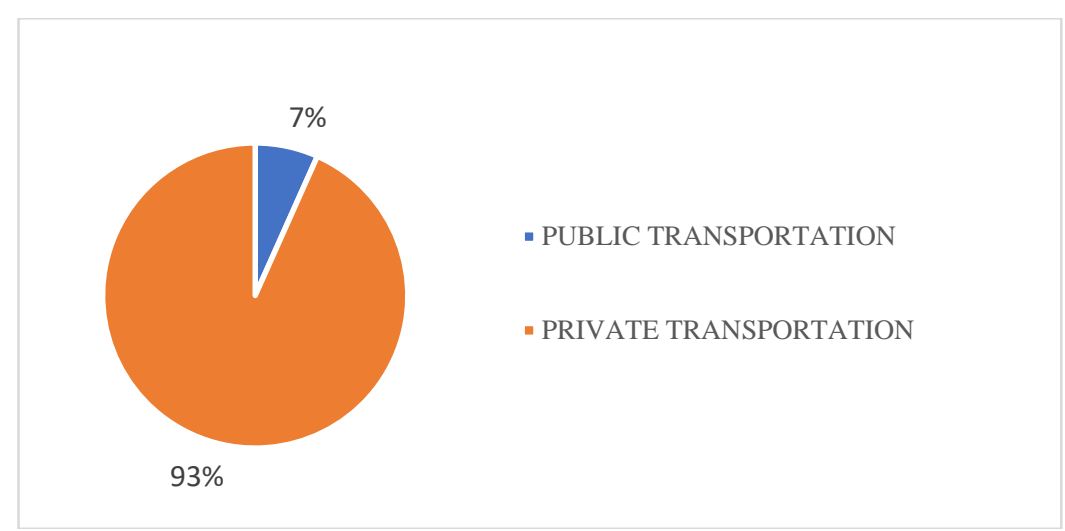

Fig. 5 - Distribution of energy used for transportation 


\subsubsection{Agriculture}

The energy sources used in the community for agricultural purposes include charcoal, diesel, electricity, firewood, gasoline, solar and energy obtained from human labour. The agricultural sector in the Alagbaa community consumes daily 3569.78 MJ (Table 5). The primary energy source to carry out the agricultural activities (e.g. planting, weeding, grinding) comes from human-power to operate hand tools with $48 \%(1723.25 \mathrm{MJ})$ of the total energy used in this sector. This is followed by diesel with $19 \%(694.80 \mathrm{MJ})$, and the least used energy source derives from solar energy with $7 \%$ $(257.81 \mathrm{MJ})$ as seen in Table 12. Gasoline and energy from charcoal and firewood take about $8 \%$, 9\% and 9\% respectively of the total energy consumed (273.60 MJ, 317.14 MJ, and 303.17 MJ respectively) as seen in Figure 5. In this community, electricity is not used for any agricultural process due to its low communal reach and insufficient supply. The average energy used per household stands at 25.5 MJ, with the maximum being 266.29 MJ and $0 \mathrm{MJ}$ for households that do not engage in agriculture at all (Table 5).

Table 12 - Daily energy consumed for agriculture from various sources

\begin{tabular}{lccccc}
\hline & $\begin{array}{c}\text { Minimum } \\
(\mathbf{M J})\end{array}$ & $\begin{array}{c}\text { Maximum } \\
(\mathbf{M J})\end{array}$ & $\begin{array}{c}\text { Sum } \\
(\mathbf{M J})\end{array}$ & $\begin{array}{c}\text { Mean } \\
(\mathbf{M J})\end{array}$ & Std. Deviation \\
\hline Charcoal & 0.00 & 171.43 & 317.14 & 2.27 & 15.68 \\
Diesel & 0.00 & 165.43 & 694.80 & 4.96 & 22.24 \\
Electricity & 0.00 & 0.00 & 0.00 & 0.00 & 0.00 \\
Firewood & 0.00 & 34.71 & 303.17 & 2.17 & 6.71 \\
Gasoline & 0.00 & 73.29 & 273.60 & 1.95 & 10.91 \\
Human-powered & 0.00 & 160.24 & 1723.25 & 12.31 & 28.75 \\
Solar & 0.00 & 12.62 & 257.81 & 1.84 & 2.99 \\
\hline
\end{tabular}

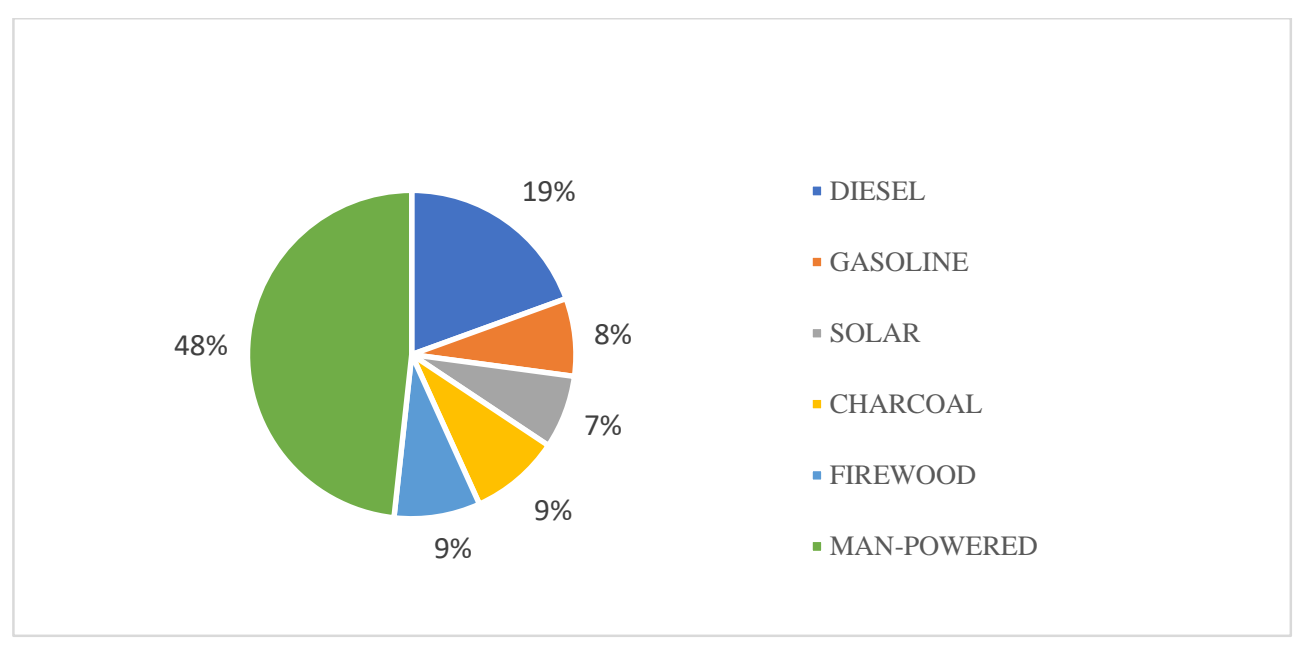

Fig. 6 - Distribution of energy used for agriculture from various sources

\section{Conclusion}

Energy consumption is closely related to economic growth, where the patterns of consumed energy shed light on the economic state and development of the location selected for the study. The total exploited energy consumed stood at approximately $24362.03 \mathrm{MJ}$ with the average being $174.01 \mathrm{MJ}$ per household. There is a large deficiency of energy resources in the community. Some of the conventional resources were not exploited in some sectors. The domestic sector consumes the highest energy for cooking and powering of home appliances (12320.87 MJ, 50\% combined). The community's agricultural sector needs to improve its methods and switch to mechanized farming to gain better economic benefits as $48 \%$ of the energy consumed comes from human labour.

In this case study, $50 \%$ of the energy consumed was channeled towards economic activities. To ensure social development, efficient management of resources, and sustainable economic development, energy planning schemes such as proper exploitation of conventional and renewable energy sources must be carefully formulated with the state and federal government's full support. 


\section{Acknowledgement}

The authors are grateful to the Department of Mechanical Engineering, University of Ibadan, Ibadan, Nigeria.

\section{References}

[1] National Population Commission, "Population distribution by sex, state, LGA and senatorial district," Federal Republic of Nigeria 2006 Population and Housing Census, Priority Table (3), 2010

[2] International Energy Agency. "Data and Statistics" https://www.iea.org/data-and- statistics? country=NIGERIA, 2020

[3] E. Dogan, "Energy Consumption and Economic Growth: Evidence from Low-Income Countries in Sub-Saharan Africa," International Journal of Energy Economics and Policy, 4(2), 154-162, 2014

[4] O.O. Gbadebo, and C. Okonkwo, "Does energy consumption contribute to economic performance?" Empirical evidence from Nigeria. Journal of Economics and International Finance, 1(2), 044-058, 2009

[5] W. Shaojian, L. Qiuying, F. Chuanglin, and Z. Chunshan, "The relationship between economic growth, energy consumption, and CO2 emissions: Empirical evidence from China," Science of The Total Environment, 542(A), 360-371. 2016

[6] A.U. Öznur, and E. Bulut, "Relationship between Energy Consumption and Real Gross Domestic Production in Turkey: A Co-Integration Analysis with Structural Breaks," International Journal of Energy Economics and Policy, 5(4), 968-978, 2015

[7] T.V. Ramachandra, D.K. Subramanian, N.V. Joshi, S.V. Gunaga, and R.B Harikantra, "Domestic energy consumption patterns in Uttara Kannada District, Karnataka State, India," Energy Conversion \& Management $41,775-831,1999$

[8] V. Devadas, "Planning for rural energy system: Part a, b, c. Renewable and Sustainable Energy Reviews," 5(3), 203-226, 2001

[9] J. Kraft, and A Kraft, "On the relationship between energy and GNP," Journal of Energy and Development, vol. 3, pp. 401-403, 1978

[10] I. S. Sachin, B.B. Lalit, and D.J. Samir, "Micro-Level Analysis of Rural Domestic Energy Consumption Pattern in India - A Case Study of Daryapur Block," International Journal of Innovations in Engineering and Technology, 2, 208-219, 2013

[11] D.G. Omotor, "Causality between energy consumption and economic growth in Nigeria," Pakistan Journal of Social Sciences, 5(8), 827-835, 2008

[12] S. Ibrahim, and J. Ukwenya, "Managing energy resources in Nigeria: studies on energy consumption pattern in selected rural areas in Benue state," Leonardo Electronic Journal of Practices and Technologies, 21, 47-61, 2012

[13] G. Li, J. Sun, and A. Dai, "Village differences in rural household energy consumption within the Loess hilly region of China," Energy, Sustainability and Society 6, 33.

[14] A. Olufemi, A. Anthony, O. Olayinka, I. Imoisime, O. Damilola and A.B. Ademola, "Investigation of Energy Use Pattern and Emission Discharge in Nigeria: A Case Study of South West Zone. International Journal of Engineering and Technology Innovation," 5(1), 56-65, 2014

[15] D. Pragyan," Consumption pattern of electricity in rural and urban areas: a case study of Rourkela, Sundergarh district of Odisha," A Dissertation Submitted to the Department of Humanities and Social Sciences, National Institute of Technology, Rourkela in Partial Fulfilment of Requirement of the Award of the Degree of Masters in Development Studies, 2014

[16] J.S. Ojo, and E.O. Olurotimi, "Tropical 1 rainfall structure characterization over two station in south-western Nigeria for radio wave propagation purposes," Journal of Emerging Trends in Engineering and Applied Sciences, 5(2), 116-122, 2014

[17] IOR Energy, "List of common conversion factors (Engineering Conversion Factors)"

Web.archieve.org/web/20100825042309/http:/www.ior.com.au/ecflist.html, 2010

[18] S. Sepp, "Multiple-Household Fuel Use - A balanced choice between firewood, charcoal and LPG," Deutsche Gesellschaft für Internationale Zusammenarbeit. 2014

[19] National Electricity Regulation Commission, "Ibadan Disco - Fixed Charge and Energy Charge. Available from: www.nercng.org, 2015

[20] G.I. Olatona, and C.W. Adegoke, "Analysis of Solar Radiation Availability for Deployment in Solar Photovoltaic Technology over a Tropical City," Journal of Environment and Earth Science, 5(13), 133-137, 2015

[21] V. K. Mittal, T.K. Mittal, K.C Dhawan, "Research Digest on Energy Requirements in Agricultural Sector," 1985 